\title{
Microscopic Characterization of Damage Produced by Frost in Cherry and Apple Ovaries
}

\author{
M. Virtudes Andrés and José M. Durán \\ Departamento de Producción Vegetal: Fitotecnia, Escuela Técnica Superior \\ de Ingenieros Agrónomos 28040-Madrid, Spain
}

\section{Eusebio Rodríguez-Almazán \\ Agrupación Española de Entidades Aseguradoras de los Seguros Agrarios Combinados, S.A. (AGROSEGURO), Gobelas 23, 28023-Madrid, Spain}

Additional index words. freezing damage, low temperatures, Malus sylvestris, Prunus avium

Flowering and fruiting of stone and pome fruit trees occurs in the spring, a time when the air temperature falls below $0{ }^{\circ} \mathrm{C}$, which may cause damage to the tissues as a consequence of ice formation. The critical freezing temperature depends on the species and the developmental stage of the organ studied (Proebsting and Mills, 1978; Ramina and Tonutti, 1989). Using a differential scanning calorimeter (DSC-6; Perkin Elmer, Norwalk, Conn.), differences have been observed (Durán et al., personal comunication) between the critical freezing temperatures of the different structures (ovary, style, and stigma) forming the flower gynoecium and small recently formed fruits in several tree-fruit species.

Depending on the rate of tissue cooling, the crystallization of ice can occur in two markedly distinct locations within the tissues. If cooling is rapid, ice may form within the tissues of most plants. Crystallization of the water inside the cell may occur by internal nucleation or by penetration into the cell by an external ice crystal. Some circumstantial evidence suggests cooling rates $>3{ }^{\circ} \mathrm{C} / \mathrm{h}$ may favor intracellular freezing in intact plants. In natural surroundings, the cooling speed is rarely $>1{ }^{\circ} \mathrm{C} / \mathrm{h}$. The ice formation that generally occurs in intercellular spaces is called extracellular freezing and normally implies cell dehydration (Guy, 1990). Dereuddre and Gazeau (1992) stated that the survival or death of a plant exposed to frost is inevitably accompanied by the redistribution of water inside the plant, which in turn is closely linked to the physical properties of the water, the cell characteristics, temperature, and cooling speed. Modlibowska (1961) showed that freezing sequence could be studied under the microscope. After coloring tissue with neutral red, it was possible to observe the changes in the vacuole associated with cell death. Neri and Filiti (1989) detected the damage produced by frost, using light microscopy of sections, after staining with safranine and fast-green.

At the histological level, the present study was designed to determine the damage caused by ice formation in the tissues of recently

Received for publication 14 Aug. 2000. Accepted for publication 22 June 2001. formed cherry (Prunus avium L.) and apple (Malus sylvestris Mill.) fruits.

The temperatures were recorded with miniaturized $(40 \times 30 \times 20 \mathrm{~mm})$ data-loggers (Tinytalk-T; Orion Group, West Sussex, U.K.) installed in the branches of selected trees. Ovaries in Fleckinger's $\mathrm{H}$ and I stages (Fleckinger, 1945) with different types of damage were collected from trees in a plot where the minimun temperature was $-4{ }^{\circ} \mathrm{C}$ between Feb.-Apr. 1995. Apparently healthy as well as deteriorated fruits (because of the lack of fertilization) were collected similarly from plots where the temperatures had remained above $0{ }^{\circ} \mathrm{C}$.

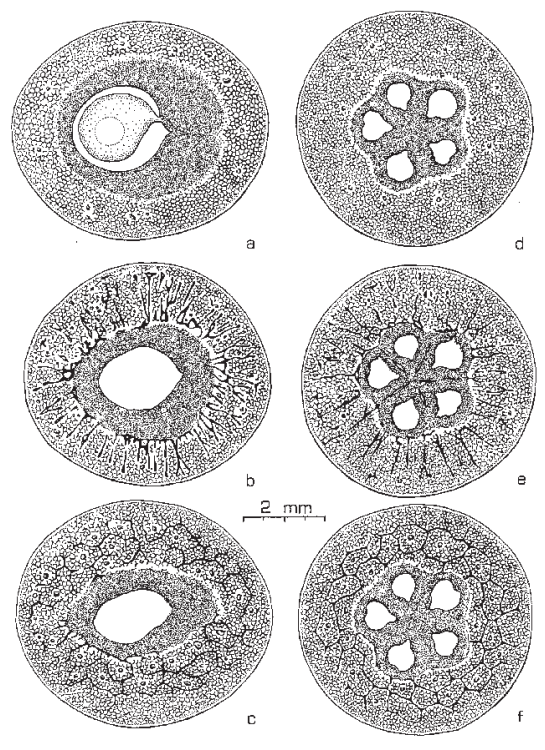

Fig. 1. Comparative damage in recently formed cherry (Prunus avium L.) and apple (Malus sylvestris Mill.) fruits, observed by microscopy. (a) Normal ovary section of cherry fruits showing the fertilized ovule. (b) Abnormal cherry fruit with mesocarp tissue broken by ice formation and undamaged endocarp. (c) Abnormal cherry fruit not damaged by frost. [Mesocarp tissue damage is identified with dehydration caused by the deterioration of dead tissue. The reticular appearance of the damage contrast with the radial dehydration distribution observed in (b)]. (d) Normal apple fruit. (e) Frost-damaged apple fruit. (f) Abnormal apple fruit not damaged by frost.
Fifty long branches of $30 \mathrm{~cm}$ were cut with most small fruit in Fleckinger's $\mathrm{H}$ and I stages (Fleckinger, 1945), taken to the laboratory and placed in beakers with a sucrose solution $(5 \mathrm{~g} / 100 \mathrm{~mL})$ and kept at different temperatures $\left(-2,-4\right.$, and $\left.-6^{\circ} \mathrm{C}\right)$ controlled by digital process controller (ES100; Omron, Tokyo); $48 \mathrm{~h}$ after treatment, fruits were collected.

A minimun of 25 samples from the previously described kinds of ovaries were evaluated. The samples evaluated had a diameter between $30-50 \mathrm{~mm}$, and were fixed in FAA [(Formaldehyde $(0.4 \mathrm{~mL})$ : Glacial Acetic acid : Alcohol (ethanol, at $0.7 \mathrm{~mL}$ ); $5: 5: 90 ; \mathrm{v} / \mathrm{v} / \mathrm{v}]$ After cutting the ovary transversely $(30 \mu \mathrm{m})$, it was stained with safranine and fast-green. The resulting preparations were studied by optical microscopy (Nikon, mod. Optiphot, Tokyo) at magnification of $\times 4$ and $\times 10$.

At $-4{ }^{\circ} \mathrm{C}, 80 \%$ of cherry fruit was frost damage; broken ovary tissue was observed, contrasting clearly with healthy tissues. The dehydration produced by frost appeared as radial intercellular spaces. There were also radial areas in which very intense dehydration alternated with broken tissues. Damage in laboratory test and in orchard freezes were similar.

The reticular appearance of the dehydration produced by the deterioration from lack of fertilization, contrasts with the radial dehydration observed from freezing.

Frost-produced dehydration and broken tissues in apple looked similar to those observed in cherry. It also was observed in the apple fruit that the most damaged area was that of the pericarp.

Fig. 1 shows the comparative damage in recently formed cherry and apple fruits. In view of the above observations, we concluded that under severe frost conditions in both cherry and apple fruit, the broken ovary tissue can be observed easily under the microscope, while tissue dehydration caused by frost has a characteristic appearance distinguishable from dehydration for other reasons.

\section{Literature Cited}

Dereuddre, J. and C. Gazeau. 1992. Les végétaux et les très basses températures, p. 109-173. In: D. Côme (ed.). Les Végétaux et le Froid. Hermann, Paris.

Fleckinger, J. 1945. Notations phénologiques et représentations graphiques du dévelopment des bourgeons de Poirier. CR. Congr. Assn. Fr. Avanc. Sci., Paris.

Guy, C.L. 1990. Cold acclimation and freezing stress tolerance: Role of protein metabolism. Ann. Rev. Plant Physiol. Plant Mol. Biol. 41:187-223.

Modlibowska, I. 1961. Sur les mecanismes du gel et de la reprise d'une vie normale au retour a la temperature ordinaire. Bul. Soc. Fr. Physiol. Vég. 7:123-133.

Neri, D. and N. Filiti. 1989. Capacità di recupero delle gemme miste di pero danneggiate dal freddo. Riv. Frutt. 2:37-40.

Proebsting, E.L. and H.H. Mills. 1978. Low resistance of developing flower buds of six deciduous fruit species. J. Amer. Soc. Hort. Sci. 103:192198

Ramina, A. and P. Tonutti. 1989. Le basi fisiologiche della resistenza al freddo. Riv. Frutt. 2:7-12. 